\title{
The Normativity of Measure in Gregory Nazianzus' and Gregory of Nyssa's Orations on Love for the Destitute Poor
}

\section{Introduction}

Gregory of Nazianzus (henceforth Nazianzen) and Gregory of Nyssa (henceforth Nyssen) composed between them three orations traditionally

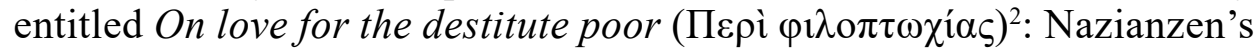
Oration 14, also known as De pauperum amore and in some manuscripts

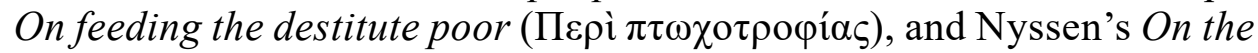
Love of the Poor 1 and 2, sometimes known respectively as On Good works (De beneficentia), and "Whoever has done it to one of these has done it to me" (In illud: quatenus uni ex his fecistis mihi fecistis). While their dating is uncertain, Oration 14 is likely to have been composed first and perhaps served as a literary model for those of Nyssen ${ }^{3}$. The orations highlight the pre-eminence for Christians of practical love for

1 Monica Tobon PhD, University College London, Honorary Research Fellow, Department of Greek and Latin, Faculty of Humanities; e-mail: m.tobon@ucl.ac.uk; ORCID: 0000-0002-0486-9972. I would like to express my gratitude to the anonymous peer reviewers of this article for their comments and suggestions.

2 S.R. Holman, Healing the Social Leper in Gregory of Nyssa's and Gregory of

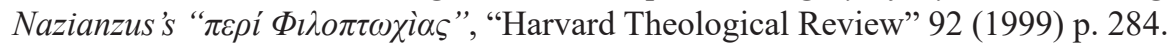

3 Holman, Healing the Social Leper, p. 284-285. But at The Hungry are Dying. Beggars and Bishops in Roman Cappadocia (Oxford 2001), she notes that "while the

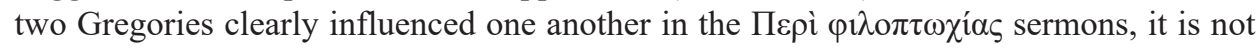
entirely clear who most influenced whom on which particulars". For detailed discussion of the date, text, and context of the three orations, see Holman, The Hungry are Dying, p. 144-148. 
the destitute, situate lepers ${ }^{4}$ as its most deserving recipients due to the unique magnitude of their misfortune as including not only disease but also social ostracisation, and argue that since to minister to the destitute is to minster to Christ, it is in lepers that he is most fully served. The present paper focuses on their analysis of social inequity in terms of the pursuit of excess and violation of measure, showing how they baptise the association in Plato's Gorgias of appetite with excess and logos with measure by appropriating the latter to the Christian Logos such that the pursuit or tolerance of excess, or its concomitants deficiency and imbalance, is shown to be contrary not only to logos but to God himself ${ }^{5}$. We shall see that while they agree that social inequity reflects soul sickness with its remedy in philanthropy, they differ in their approaches. To contextualise my discussion I begin by outlining the late antique notion of the $\pi \tau \omega \chi o$ oi and the salient aspects of Plato's Gorgias, and I conclude by highlighting the orations' anticipation of Pope Francis' call to Christians to "go forth to the peripheries"', considering who the figure of the leper symbolises today and implicitly for the Gregories, and how my discussion illuminates the contrasting views expressed in Nazianzen's Oration 43 and Nyssen's Quatenus uni regarding the Basileias and institutional care for lepers.

4 Holman (Healing the Social Leper, p. 287) notes that the term "leprosy" in fact translates several Greek terms including $\lambda \varepsilon \dot{\pi} \rho \rho, \lambda \varepsilon v ́ \kappa \eta$, and $\psi \omega ́ \rho \alpha$, referring to a variety of skin conditions that made the sufferer a social outcast. I use the term "leper" for convenience but with reservation due to the potential it shares with all class nouns to imply a de facto denial of particularity and individual dignity through subsumption under, or worse, reduction to, a single characteristic. The imperative for Christians to avoid such denial is a core message of these orations.

5 McGuckin notes Oration 14's use of the Hellenistic ethical categories of "balance" and "measure" but only associates them with Aristotle's doctrine of the Mean and the concept of $\mu$ oĩ $\alpha$ as "Fate/allotted measure". Cf. J.A. McGuckin, St. Gregory of Nazianzus on the Love of the Poor (Oration 14), in: The Ecumenical Legacy of the Cappadocians, ed. N. Dumitrascu, Basingstoke 2016, p. 148-149, 156, n. 35.

6 Cf. Franciscus, Evangelii Gaudium 1, 20. 


\section{Preliminary considerations}

\subsection{The $\pi \tau \omega \chi 0$ ó}

Holman notes that the Greek literature of late antiquity commonly uses one of two words to denote a pauper, $\pi \dot{\varepsilon} \vee \eta \varsigma$ or $\pi \tau \omega \chi \alpha_{\delta} \varsigma$, and that while the distinction between them was "hardly absolute", $\pi \dot{\varepsilon} v \eta \varsigma$ generally referred to those who had minimal economic resources but nonetheless functioned as part of the community, with homes, families, and commitments, including their debts, and $\pi \tau \omega \chi$ ó $\varsigma$ to the extreme poor: the "destitute beggar" existing either at the margins of society or outside of it altogether. According to Origen, "a $\pi \tau \omega \chi$ ó $\varsigma$ is one who has fallen from wealth, whereas a $\pi \dot{\varepsilon} v \eta \varsigma$ is one who earns a living by labour"7, and according to Basil "a $\pi \tau \omega \chi$ ó $\varsigma$ is one who falls from wealth into need, but a $\pi \dot{\varepsilon} v \eta \zeta$ is one who is in need from the beginning and is acceptable to the Lord", thus Basil also asserts a moral distinction between them, with the $\pi \tau \omega \chi$ ó $\varsigma$ "the more contemptible". All three orations are expressly concerned with $\pi \tau \omega \chi 0 i$, of whom they take lepers to be the most extreme, and therefore paradigmatic, case, and Holman notes that they provide one of the most extensive descriptions of leprosy from a fourth century Christian perspective, both in its physical manifestation and as spiritual metaphor $^{10}$. In contrast to the Hebrew scriptures neither medical nor early Christian texts consider leprosy in terms of ritual impurity, and neither Greek nor Roman medical texts include religious rites in their prescriptions for it. But nonetheless it aroused a singular disgust and dread even among Christians, and Graeco-Roman culture, including in its Christian forms, ostracised lepers ${ }^{11}$. Yet not only do the Gregories focus on leprosy at length, but in order to rouse their listeners to metanoia, compunction,

\footnotetext{
Origenes, Fragmenta in Psalmos 11, 6 (tr. M.T.).

Basilius Caesariensis, Regulae brevius tractatae 262 (tr. M.T.).

Holman, The Hungry are Dying, p. 6.

10 Cf. Holman, Healing the Social Leper, p. 284; Holman, The Hungry are Dying,
} p. 144. Holman (Healing the Social Leper, p. 296) notes that they display "a rhetorical tendency to talk around the actual subject, perhaps finding it as provocative a sermon topic as cancer and AIDS have been in twentieth-century theological discussion", thus the word $\lambda \varepsilon \dot{\pi} \rho \alpha$ occurs only once in Oration 14, and Nyssen "reflects a similar reluctance to speak directly and openly of this ailment as «leprosy» and its victims as «lepers»".

11 Holman, Healing the Social Leper, p. 286. 
and compassion they spare no effort in describing its physical, psychological, and social impact upon its sufferers.

\subsection{Measure and logos in Plato's Gorgias}

Plato's Gorgias addresses the ethical dimensions of the practice of rhetoric as a form of logos by reference to the wider connotations of that multivalent term, in particular those it acquired in the thought of Heraclitus. Long explains that in developing his concept of logos Heraclitus drew not only upon its core meanings of discourse, account, ratio, and reckoning, but

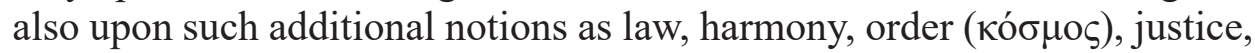
temperance ( $\left.\sigma \omega \varphi \rho \sigma^{\prime} v \eta\right)$, commonality, and measure, with the latter most fully capturing its essence and embracing cosmology, psychology, and ethics ${ }^{12}$. All are at play in the Gorgias ${ }^{13}$. Socrates engages three interlocutors, starting with Gorgias himself, on the question of whether the teacher of rhetoric instructs his students regarding justice so that they will know how to use their power of speech, $\lambda$ ófos, justly. Through increasingly charged exchanges he argues for the far-reaching psychological and social consequences of failing to observe the normativity of logos in its wider senses. The strand of his argument which concerns us here can be summarised as follows. Measure is intrinsic to logos. The human soul comprises logos and appetites, the former its natural ruler, the latter insatiable and dependent on logos for regulation. Whereas logos is directed at the good and penetrates beyond appearances, appetites are directed at pleasure and appearances. Socrates opposes practices such as pastry-cooking, which are forms of pan-

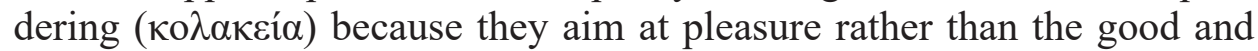

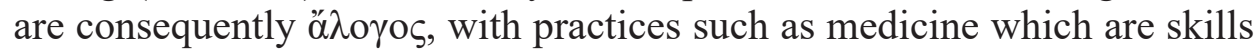
( $\tau \varepsilon \dot{\varepsilon} \chi \alpha \iota$ ) because they aim at the good and have a logos in the sense of a rational explanation for their procedures ${ }^{14}$. Insofar as a person is ruled by their appetites they lack measure, are motivated by the pursuit of pleasure and avoidance of pain, and judge by appearances alone. As a result they take more than their share, meaning that they practise alienation and conflict

12 Cf. A.A. Long, Heraclitus on measure and the explicit emergence of rationality, in: Body and Soul in Ancient Philosophy, ed. D. Frede - B. Reis, Berlin 2009, p. 87-88.

13 Long (Heraclitus on measure, p. 91) leaves open the question of whether Heraclitus influenced Plato's understanding of $\lambda$ ó $\gamma$ os directly or simply "the intellectual climate in which Plato found himself'.

14 Cf. Plato, Gorgias 463a-465e. 
instead of friendship and cooperation. In a key passage Socrates responds to the claim that the best life is one of unrestrained appetitive indulgence:

The wise say $[\ldots]$ that heaven and earth and gods and humans are bound to-

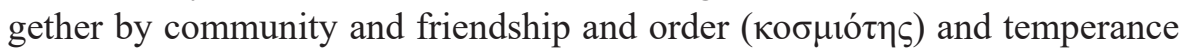

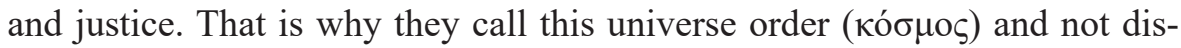

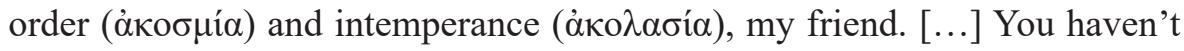

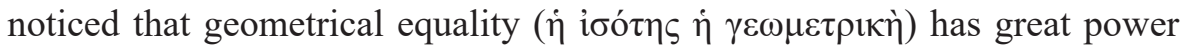
among gods and humans; you think you should practise taking more, because you are heedless of geometry ${ }^{15}$.

Community, friendship, and the cosmos qua cosmos all depend upon the normativity of logos and only those who respect it by living according to logos participate in them. Those who live according to their appetites are deceived by appearances into suffering, enacting, and perpetuating alienation and conflict. All this is echoed in the present orations, which appropriate the association of measure with logos to the Christian Logos such that to follow him means to observe measure. The expression

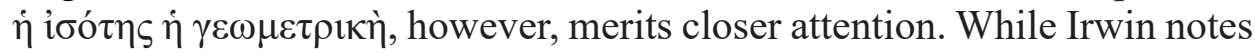
that a general reference to "the importance of order, system, and proportion" might be all Socrates intends by it here ${ }^{16}$, he explains that it "normally refers to some proportional arrangement, as opposed to numerical (or «arithmetical») equality"17. Dodds, who renders it "proportional equality", suggests that it is "the Pythagorean answer to the democratic slogan of «equality»" described in Euripides' Phoenician Women where, associating 'Iбó $\rceil_{\varsigma}$ with justice, Jocasta explains that as well as giving humankind number, measures, and weights, Equality "binds friends to friends, cities to cities, and allies to allies". In its absence, she says, enmity arises, since "the lesser is always hostile to the greater and making war against it" $"$. In his Laws, Plato makes the opposite case. There are, he says, two forms of

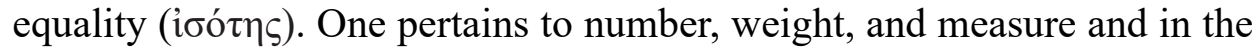
political sphere corresponds to bestowing equal honours on all people regardless of their status or worth. But because there can never be friendship between a master and his slave nor between an honest person and a scoun-

15 Plato, Gorgias 507e6-508a8 (tr. M.T.).

16 T. Irwin, Plato: Gorgias, Oxford 1979, p. 226.

17 Cf. E.R. Dodds, Plato. Gorgias, Oxford 1959, p. 339; Irwin, Plato. Gorgias, p. 226.

18 Euripides, Phoenissae 536-540, tr. D. Kovacs, Euripides. Helen, Phoenician Women, Orestes, Cambridge 2014, p. 265. 
drel, it leads only to discord since it does not observe due proportion $(\mu \grave{\eta}$

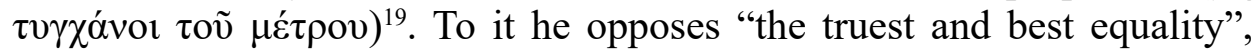

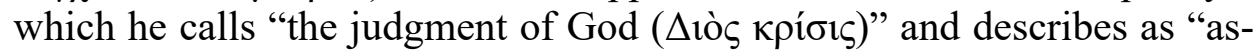
sign[ing] more to the greater and less to the lesser, adapting its gifts to the real nature of each", thereby "dealing proportionately according to logos

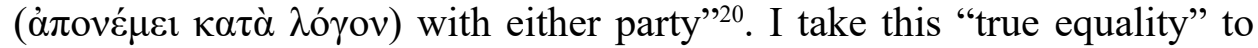
be what the Gorgias refers to ${ }^{21}$. While it will find reflection in Oration 14 and the Evagrian and Dionysian hierarchies, if applied to human nature simpliciter it is antithetical to Christianity's assertion of the equal dignity of every human individual in virtue of our creation in God's image. The present orations strongly affirm that doctrine by grounding their exhortation to $\varphi \imath \lambda o \pi \tau \omega \chi i \alpha$ in it. Since every human being bears God's image, the same measure is due to each ${ }^{22}$, and so while they agree with Plato that to observe measure means to practise temperance, discernment, and justice, they also insist that these virtues find their perfection in practical compassion for the neediest among us. Their inclusion of lepers within the scope of the Christian vocation to charity also departs from Plato in that in the Republic he has Socrates inveigh against treating the chronically ill on the grounds that in a well-ordered city each person has work assigned to them and so "no-one has the leisure to be sick and doctor himself all his days" In the Gregories' baptised version of Platonic logos, to observe measure in respect of philanthropy means to practise it as fully as possible and thereby to imitate, as far as we can, God's unsurpassable love for every human being ${ }^{24}$.

19 Plato, Leges 757a.

20 Plato, Leges $757 \mathrm{bc}$.

21 I believe Plato's views to have remained essentially unchanged throughout his writing career. Other exponents of the "unitary" reading of Plato include C. Shields, Simple Souls, in: Essays on Plato's Psychology, ed. E. Wagner, Lanham 2001, p. 137-156, and C.H. Kahn, Plato and the Post-Socratic Dialogue: The Return to the Philosophy of Nature, Cambridge 2013.

22 Cf. McGuckin, St. Gregory of Nazianzus on the Love of the Poor, p. 148.

23 Plato, Respublica 406c.

24 Cf. Gregorius Nazianzenus, Oratio 14, 22. 


\section{Gregory Nazianzus' Oration 14}

\subsection{Overview}

Nazianzen's Oration 14 comprises 8,162 words according to the Thesaurus Linguae Graecae and is divided thematically into forty paragraphs. As Vinson notes, it is not tightly structured but displays the flexibility and disorder characteristic of the rhetorical format of the $\lambda \alpha \lambda \lambda_{1}$ or or talk, with Nazianzen "[passing] from one theme to another, carried along, as it were, by the free association of his thoughts" 25 . That it nonetheless articulates a clearly structured argument becomes apparent when it is summarised according to the main theme of each paragraph:

- 1 prologue;

- 2-5 the virtues;

- 6-8 the body's physical vulnerability and contribution to moral vulnerability;

- 9-14 the plight of lepers;

- 15-18 excess and soul sickness;

- 19-22 the remedy: to follow the Logos through temperance, discernment, and charity;

- 23-28 initial applications of discernment;

- 29-34 further applications of discernment;

- 35-36 practical charity in our own interests;

- 37-39 mercy and compassion mandatory for Christians;

- 40 to minister to the poor is to minister to Christ.

Its argument can be outlined as follows. All virtues are praiseworthy but the greatest is practical love for victims of misfortune, above all lepers. The human being bears God's image but is joined a body which is both physically and morally vulnerable. Lepers are betrayed by the body when it succumbs to disease but we are betrayed by it when, led by its appetites instead of by logos, we practise excess. Our doing so results both in the surfeit of the prosperous and the privation of the destitute and reflects a sickness of the soul worse than any physical malady. The remedy is to fol-

25 M. Vinson, St. Gregory of Nazianzus. Select Orations, The Fathers of the Church, Washington 2003, p. 39-71, xix. 
low the Logos by learning temperance: soundness of mind characterised by discernment and reflected in the practice of measure. Discernment means distinguishing the better from the worse and pursuing the former and avoiding the latter, and Nazianzen describes how to do so by recognising God as the source of our existence, his providential care for creation, our own vocation to good stewardship, our present enslavement to the devil's deceitful tyranny, and by rejecting false doctrines and excuses for neglecting the poor. The oration concludes by affirming that to practise love is both mandatory for Christians and in our own best interests and that to minister to lepers is to minister to Christ himself.

\subsection{The vulnerability of the body}

The initial paragraphs of Oration 14 comprise a survey of the virtues which concludes with an affirmation of the priority of the commandment to $\varphi \imath \lambda \mathrm{o} \pi \tau \omega \chi i \alpha$ and a reminder that God "weighs mercy in his scale and balance and gives just recompense" 26 . Nazianzen then proceeds to lay the foundation for his analysis of social inequity in terms of the pursuit of excess. Observing that lepers have been "betrayed by this wretched, base, and untrustworthy body $(\sigma \tilde{\omega} \mu \alpha)^{\prime 2}$. he continues:

How I came to be joined to it, I do not know; nor how I am the image of God and concocted of clay at the same time, this body that both wars against me when healthy and complains ( $\dot{\alpha} v i \alpha \dot{\alpha} \omega)$ when warred against, that I both cherish as my fellow-servant and evade as my enemy; that I both try to escape as my chain and respect as my fellow heir. If I struggle to suppress it, I lose the helper I need to achieve my noble aims, knowing as I do why I was created and that it is through my actions that I am to ascend to God. I show it consideration as a co-worker but I do not know how to suppress its insurgency nor how I can help falling away from God when the weight of its shackles drags me down and keeps me pinioned to the ground. [...] What an incompatible alliance $!^{28}$

26 Gregorius Nazianzenus, Oratio 14, 5. Translations of Oration 14 are by Vinson with my own amendments.

27 Gregorius Nazianzenus, Oratio 14, 6. Č. Milovanović ("Here I am a Breathing Corpse": did Gregory of Nazianzus Suffer from Leprosy?, "Analecta Bollandiana" 127 (2009) p. 273-297) argues that Nazianzen himself suffered from leprosy in his later life.

28 Gregorius Nazianzenus, Oratio 14, 6-7. 
The passage has echoes of Rom. 7:15-23, but whereas Paul is concerned only with the body's moral vulnerability ${ }^{29}$, Nazianzen starts from its susceptibility to physical disease and proceeds to its moral vulnerability, the latter arising from the appetites which, except in the Phaedo, Plato attributes to the soul. When Nazianzen speaks of the body's untrustworthiness he is referring both to its purely physical nature and its appetitive aspect. The former is untrustworthy in its susceptibility to bodily infirmity, the latter in virtue of the appetites' insatiability, their orientation to pleasure instead of the good and appearances instead of reality, and their involvement, via misdirected desire, in every vice. He concludes his reflection on the body's vulnerability by suggesting that God wills that its weakness should remind us of our dependence upon him, lest we who are a "portion ( $\mu$ oĩp $\alpha)$ of God" should through pride disdain him ${ }^{30}$. In classical thought $\mu$ oĩp $\alpha$ has connotations of a person's destiny and can refer in particular to their "appointed doom" in the sense of their death, so here it can be understood as in terms of the question and answer of Rom. 7:24-25: if we choose the body as our portion it becomes "the body of this death", but if we choose God then we, including our body, shall live. To do so means living according to logos and measure, whereas to be ruled by our appetites is to allow them excessive influence, an excess reflected in, and compounded by, that of the dispositions and acts to which it gives rise.

\subsection{Excess}

Nazianzen concurs with Christian ascetic tradition as exemplified by Evagrius in considering the primary the primary locus of appetitive insatiability to be the belly ${ }^{31}$. He echoes the Gorgias when he speaks of

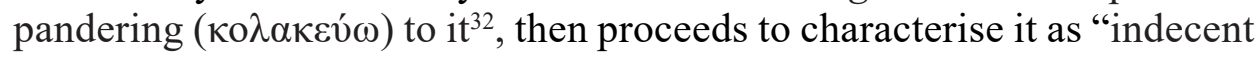

29 We should accordingly be wary of supposing that the word $\sigma \tilde{\omega} \mu \alpha$ means to Nazianzen, Paul, or Evagrius what our word "body" means to us, as if they shared a single referent independent of the interpretations we place upon it. Coakley speaks of the naïvité of imagining "that bodies provide us with an Archimedean point, a «natural» datum of uncontentious physicality", and Holmes similarly rejects "the idea of a self-evident, ahistorical body". Cf. Religion and the Body, ed. S. Coakley, Cambridge 1997, p. 3; B. Holmes, The Symptom and the Subject. The Emergence of the Physical Body in Ancient Greece, Princeton 2010, p. 7.

30 Cf. Gregorius Nazianzenus, Oratio 14, 7.

31 Cf. M. Tobon, Apatheia and Anthropology in Evagrius of Pontus, London 2021 (chapter 7, part 1).

32 Gregorius Nazianzenus, Oratio 14, 17. 
and ungrateful, that oppressive burden and author of evils, that most insatiable and treacherous beast" 33 . Its treachery overlaps with the body's moral untrustworthiness and has two aspects. The first is that its insatiability means that to pursue its gratification is to become enslaved to futility; the Gorgias likens trying to satisfy the appetites to trying to fill a leaking jar with water ${ }^{34}$. Second, for reasons I discuss in relation to Nyssen's De beneficentia, Christian ascetic doctrine as exemplifed by Evagrius maintained that for both physical and psychological reasons dietary over-indulgence promotes other disorderly behaviours ${ }^{35}$, which I take to be why Nazianzen describes the belly as indecent and "author of evils". Oration 14 cites as examples the pursuit of sensual pleasure, material possessions, and a reputation of being "extravagant voluptuaries" 36 , the desire for perishable goods ${ }^{37}$, fear of dishonour or contagion (he discounts the latter as a real possibility and thus legitimate concern $)^{38}$. Intrinsic to all is a lack of regard for others; Nazianzen cites Micah to the effect that excess "breeds a wanton contempt for others" 39 , and refers to the devil as the alien one $\left(\text { o } \dot{\alpha} \lambda \lambda \text { ó}_{\rho} \rho \iota_{0}\right)^{40}$. There is accordingly a direct causal link between practising excess, lack of feeling ( $\dot{\alpha} v \alpha \lambda \gamma \eta \tau$ ć $\tau \alpha \tau \sigma \zeta)$ for others ${ }^{41}$, and alienation. It is because of our pursuit of excess that we "revel amid the misfortunes of our brothers" 42 and "make no attempt to succour our humble fleshly existence" ${ }^{43}$.

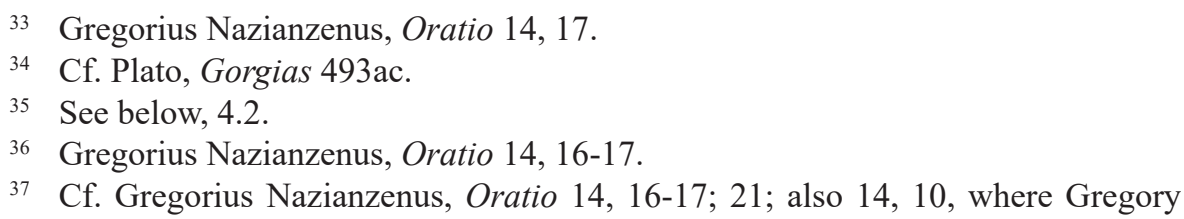
cites the belief that avoiding lepers will ensure the well-being of our own bodies; while Vinson (St. Gregory of Nazianzus. Select Orations, p. 46) has "persons", the Greek is $\sigma \omega \mu \alpha ́ \tau \omega v$.

38 Cf. Gregorius Nazianzenus, Oratio 14, 27.

39 Gregorius Nazianzenus, Oratio 14, 24. More precisely, as Vinson (St. Gregory of Nazianzus. Select Orations, p. 57, n. 100) notes, he cites Am. 6:4-7, which he attributes to Micah either lapsu memoriae or in conflation with Mi. 6:10-16.

40 Gregorius Nazianzenus, Oratio 14, 27.

41 Evagrius, De malignis cogitationibus 11, describes a demon of insensibility ( $\dot{\alpha} v \alpha \iota \sigma \theta \eta \sigma i \alpha)$ who is associated with vainglory and put to flight by ministering to those suffering misfortune.

42 Gregorius Nazianzenus, Oratio 14, 18.

43 Gregorius Nazianzenus, Oratio 14, 18. 


\subsection{Soul sickness}

Following his reflection on bodily vulnerability Nazianzen turns to the plight of the lepers. Betrayed by their bodies, they suffer "the most abhorrent and oppressive evil of all" 44 . Yet while Christians should show them compassion, taking their lead from Christ and "learning piety and kindness from our common weakness" 45 , the prosperous live in luxurious homes and dress in clothing which "exceeds the bounds of need or practicality" while lepers languish in doorways, "shivering [...] in tattered rag$\mathrm{s}$ "46. Because the same measure is allotted to all human beings this state of affairs violates both our measure and theirs, and being voluntary it reflects

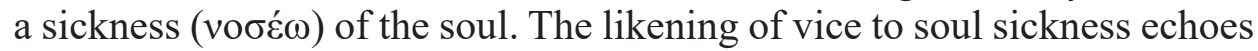
the Gorgias, which likens justice and injustice in the soul to bodily health and sickness, and also the Republic, where Socrates declares virtue to be "a certain health and beauty and good disposition of the soul" (ن́yíctó $\tau \dot{\varepsilon} \tau \imath \varsigma$

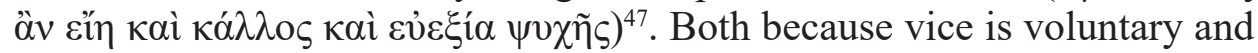
because it remains with us when we depart this life, it is worse than any bodily sickness, so by implication worse than leprosy ${ }^{48}$. Socrates seeks to remedy the soul's ill health through dialectic and the present oration is likewise therapeutic in its intent, aiming to remedy soul sickness by exposing and correcting faulty beliefs and thereby calling its hearers to conversion, compunction, and compassion. Nazianzen tells them that "anguish is sometimes more valuable than pleasure, sadness than celebration, meritorious tears than unseemly laughter"49, and that whether they like it or not, lepers are our "brothers in God" and perhaps keep his image better than we do ${ }^{50}$. In citing the discomfort his words might cause them he alludes to the role of appetite in their attitude toward lepers and by extension to the inaccuracy of their view of them, based as it is upon appearances alone. A subtext of his emphasis on the common nature they share with lepers is that they too could fall prey to leprosy; later he will state directly that bodily ills are ever present to everyone who has a body ${ }^{51}$.

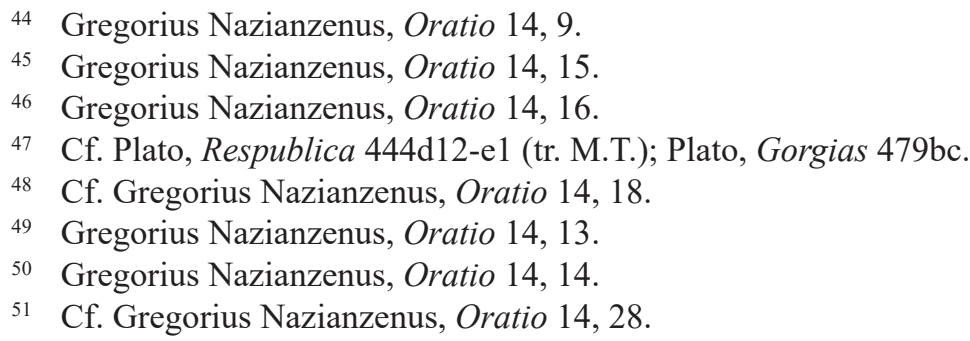




\subsection{Temperance}

Having diagnosed his listeners' soul sickness, Nazianzen exhorts them: "Will we never learn temperance ( $\sigma \omega \varphi \rho v^{\prime}(\omega)$, however late? Will we not repudiate our want of feeling ( $\alpha v \alpha \lambda \gamma \eta \sigma i \alpha)$, not to say petty selfishness? Will we not take note of our human condition?"52. To learn temperance is not simply to moderate one's behaviour but to acquire the soundness of mind which disposes to moderation; not merely to obey precepts but to undergo a conversion in one's way of thinking from a philosarkic ${ }^{53}$ perspective which sees the practice of excess as permissible or even desirable, to one which grasps the reality the human condition. With this in mind Nazianzen recalls the ephemeral nature of all material advantages and proposes that the craftsman ( $\left.\tau \varepsilon \chi v^{\prime} i \tau \zeta\right)$ Logos contrived the instability of earthly life so that when we contemplate it we shall pursue the stability of the world to come by seeking God ${ }^{54}$. The adjective $\tau \varepsilon \chi v i ́ \tau \eta \varsigma$ recalls the Gorgias' opposition between $\kappa о \lambda \alpha \kappa \varepsilon i ́ \alpha$, associated with the appetites, and $\tau \varepsilon \dot{\chi} \chi \eta$, associated with normative $\log \mathrm{s}^{55}$, and I take it to reflect Nazianzen's appropriation to the Christian Logos of the connotations of normative logos in the Gorgias, reiterated later in the oration when he describes God as $\tau \varepsilon \chi v i t \eta \varsigma^{56}$. Through it he affirms the rational order of creation and God as its author, and by implication the corollary, that to practise excess violates that order and opposes God; Nazianzen prays that God will preserve him from enjoying prosperity when lepers are in want, health without trying to assuage their wounds, or food, clothing, and a comfortable home without sharing them ${ }^{57}$.

Integral to temperance is the ability to distinguish between apparent and true goods. Despite knowing material prosperity to be transient, we are so enslaved to its "deceptive pleasure" that we cannot imagine anything better, despite having been taught and believing that we are created in God's image ${ }^{58}$. Insofar as we are in thrall to our appetites, whatever promises to gratify them will seem to be the good. To be able to judge whether something is truly good it is necessary to rise above the perspective of the flesh, and Nazianzen now turns to instructing his hearers in how to do so.

\footnotetext{
52 Gregorius Nazianzenus, Oratio 14, 19.

53 Cf. Gregorius Nazianzenus, Oratio 14, 27.

54 Gregorius Nazianzenus, Oratio 14, 20.

55 See above, 2.3 .

56 Cf. Gregorius Nazianzenus, Oratio 14, 31.

57 Gregorius Nazianzenus, Oratio 14, 18.

58 Cf. Gregorius Nazianzenus, Oratio 14, 20.
} 
He begins by presenting them with a series of oppositions including appearance and reality and flesh and spirit, then declares blessed the person who "distinguishes between these things, dividing them in accordance with the cut ( $\tau$ o $\mu$ í) of the Logos that divides the better from the worse" ${ }^{29}$. This time the characterisation of the Logos is biblical, based on Heb. 4:12. The person who exercises such discernment is blessed because being able to see the reality of the human condition they will seek "the things that are above" ${ }^{\prime 60}$. Nazianzen continues:

So now let us follow the Logos; let us seek the repose on high; let us cast aside surplus here below; let us have recourse only to that which is beneficial; let us gain our lives by practising mercy; let us share what we have with the poor that we may be rich in the bounty of heaven ${ }^{61}$.

This is the oration's third and final mention of the Logos and contains the first two in that to follow the Logos involves both artistry and skill (the

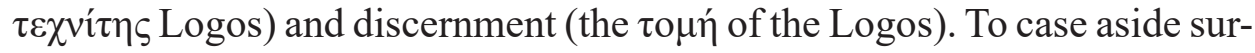
plus and have recourse only to what is beneficial is to practise temperance by observing measure, and to observe measure in the practice of mercy is to imitate God's mercy and generosity as far as we can by sharing what we have with others, especially the neediest. Our doing so should be guided by "our original egalitarian (ioovovo $\mu$ í $\alpha$ ) status"62 and imitate God's equality (iøó $\rceil \varsigma)^{63}$; we can note the contrast with Plato's proportional equality ${ }^{64}$. But when Nazianzen goes on to explain, in terms taken up by Dionysius in relation to hierarchy, that our affinity to God lies above all in doing good, with each doing so according to their power, he on a greater scale and we on a lesser, so that in this way God, having created and freed us, "gathers

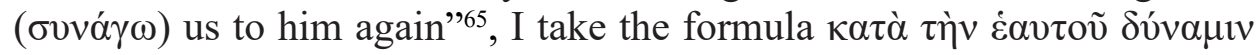
to amount to a version of proportional equality ${ }^{66}$. People are not expected

\footnotetext{
59 Gregorius Nazianzenus, Oratio 14, 21.

60 Gregorius Nazianzenus, Oratio 14, 21; Col. 3:1.

61 Gregorius Nazianzenus, Oratio 14, 22.

62 Gregorius Nazianzenus, Oratio 14, 26.

63 Gregorius Nazianzenus, Oratio 14, 24. Gregory is citing Petrine apocryphal material; cf. Vinson, St. Gregory of Nazianzus. Select Orations, p. 57, n. 97.

64 See above, 1.2.

65 Gregorius Nazianzenus, Oratio 14, 27; cf. Dionysius Areopagita, De caelesti hierarchia 1,1 .

66 Gregorius Nazianzenus, Oratio 14, 27.
} 
to contribute more than they can and those unable to contribute financially can do so in other ways; Nazianzen suggests donating food, clothing, or medicine, bandaging wounds, taking an interest in lepers' welfare, keeping them company, and showing them compassion and sympathy. The oration's conclusion will emphasise that to do these things to lepers is to do them to Christ $^{67}$.

\subsection{Honouring Christ through the poor}

The remainder of the oration expands further upon the practice of discernment before returning to the pre-eminence of mercy. Referencing the distinction between appearance and reality Nazianzen dismisses the possibility of inferring from a person's physical circumstances to the state of their soul and warns that to admire health or loathe disease for their own sake is to value them excessively ${ }^{68}$. To care for God's creature is to honour God himself and to practise mercy purifies the soul of sickness ${ }^{69}$. Echoing his earlier reference to God "weighing mercy and giving just recompense" $" 70$ Nazianzen reminds his listeners that in the parable of the sheep and the goats people are condemned because "they did not serve Christ through the poor"71. He concludes with an exhortation to visit, heal, feed, clothe, welcome, and honour Christ through the poor, offering him mercy and kindness through those who are "today downtrodden, so that when we depart this world they may receive us into the eternal habitations in Christ himself" 72 . The oration therefore ends on a purely biblical note of balance, expressed in terms of reciprocal relationality.

\subsection{Conclusion}

Oration 14 traces an ascent from recognition of the bodily vulnerability we share with lepers, through diagnosis of the soul sickness reflected in our practice of excess, to its remedy in the practice of measure in the form

\footnotetext{
67 Cf. Gregorius Nazianzenus, Oratio 14, 27-8, 40.

68 Cf. Gregorius Nazianzenus, Oratio 14, 29-34.

69 Cf. Gregorius Nazianzenus, Oratio 14, 35-38.

70 See above, 2.2 .

71 Gregorius Nazianzenus, Oratio 14, 39; Matt. 25:32-33.

72 Gregorius Nazianzenus, Oratio 14, 40; Luke 16:9.
} 
of temperance, discernment, compassion, and mercy. Through discernment we distinguish the true good from apparent goods and prioritise it, recognising the common human nature and dignity we share with lepers and that we are called to imitate God's care for creation by sharing what we have with the needy. To serve the poor is to serve Christ, and in doing good we most fully express our affinity to God and are gathered to him.

\section{Gregory of Nyssa's orations On love of the poor 1 and 2}

\subsection{Overview}

Gregory of Nyssa's orations On love of the poor 1 and 2 form a pair, with the second picking up where the first leaves off. Both are well under half the length of Oration 14, the first comprising, according to the Thesaurus Linguae Graecae, 3,136 words and the second, 3,721 words, and unlike Oration 14 they are not divided into numbered paragraphs, so the numbering in the following summary refers only to the succession of topics.

On love of the poor 1: De beneficentia:

- 1 Prologue;

- 2 Fasting and virtue;

- 3 The poor and the doubly poor;

- 4 The dignity of the poor;

- 5 Vision of judgment;

- 6 Beneficence/Providence;

- 7 Living for the flesh versus living for God;

- 8 Discernment and temperance;

- 9 A myriad of Lazaruses;

- 10 Judgment and prudence;

On love of the poor 2: In Illud: quatenus uni ex his fecistis mihi fecistis:

- 1 Vision of judgment;

- 2 Exhortation to charity;

- 3 The plight of lepers;

- 4 Our common nature but lack of feeling;

- 5 The plight of lepers;

- 6 Our common nature and vulnerability; 
- 7 Exhortation to charity;

- 8 No need to fear contagion;

- 9 Need to overcome loathing;

- 10 Exhortation to charity.

Nyssen starts from the observation that fasting has no value unless accompanied by abstinence from vice. Christians should level out disparities of circumstance by practising self-control and charity, and rather than despise the destitute should see in them the Saviour's countenance. In order to teach the value of beneficence the parable of the sheep and goats teaches that those who neglect the poor will be condemned. We should be prudent lest we share the fate of the rich man at whose gate Lazarus lay. This means living for God rather than for the flesh, moderating our needs, not being deceived by ephemera, sharing with the poor, and above all practising compassion and mercy towards lepers. Recalling that we share the same nature as them we must not rend the unity of the spirit by rejecting them but instead overcome our lack of feeling, our fear, and our revulsion, none of which have any rational basis. By ministering to lepers' physical wounds we can heal the wounds our sins have inflicted upon our souls. To overcome the loathing their sickness arouses in us is hard but we should not expect the way of virtue to be easy and by practising love we shall attain to the promised land.

\subsection{Excess as pathos}

Nyssen begins De beneficentia by declaring that, having on the previo-

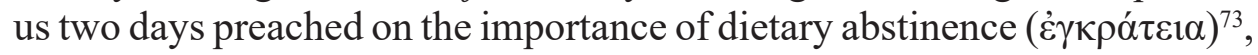
he will now proceed to more mature teachings, namely "incorporeal fasting and immaterial abstinence": fasting from evil, exercising self-control

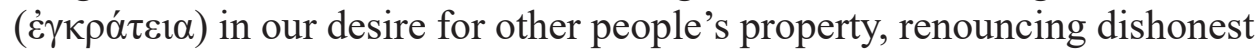
gains, starving to death our greed in respect of Mammon ${ }^{74}$. Citing Isaiah 56:6-7 he calls upon those who practise abstinence to practise justice towards, share their bread with, and receive into their homes the naked and homeless who are everywhere visible, and he notes too the importance of

73 That Gregorius Nyssenus (De beneficentia 96) notes that fasting commemorates the Lord's passion suggests that these orations were delivered during Lent.

74 Cf. Gregorius Nyssenus, De beneficentia 93-95. 
avoiding idle talk and speaking only at the proper time and with measure ${ }^{75}$. The progression from physical fasting to abstention from moral evil reflects the fact that for him "gluttony is aetiologically linked to other forms of vice" 76 a view also found in Evagrius ${ }^{77}$. We can get a sense of how he would have preached on fasting, and further insight into its significance for him, from his De virginitate, which Cadenhead considers to date from the same period as the present orations ${ }^{78}$.

When the pleasures of eating and drinking are excessive, through their lack of measure they produce in the body the necessity of unwanted evils, with surfeit engendering in people these many pathe [...] maladies [originating] from satiety. [...] [By way of remedy] we should set our minds upon a more self-controlled regimen, with the measure and limit of our enjoyment being not pleasure but need on each occasion ${ }^{79}$.

Through lacking measure dietary excess arouses in the body compulsions to "unwanted evils" which Gregory describes as pathe. I take these to correspond, at least roughly speaking, to the ethical pathe which for Evagrius dispose the soul to sin. This particular sense of the multivalent word "pathos" originates with the Stoics but, starting with Clement of Alexandria and most clearly exemplified by Evagrius, was appropriated to Christian asceticism ${ }^{80}$. Undoubtedly influenced by the Gorgias, the Stoics define pathos in opposition to logos. For them a pathos is a false value judgment and excess is intrinsic to it since to value something falsely is to ascribe excessive value or disvalue to it. This excess is reflected in the ensuing impulse toward or away from the object in question ${ }^{81}$. For Evagrius pathos is the affective dimension of the logismoi, the thoughts that tempt us to sin, and he regards it as both somatic and psychological in that, while it manifests as desires, emotions, and moods, it is fuelled by the surplus vital heat which results from eating and drinking more than the body needs

75 Cf. Gregorius Nyssenus, De beneficentia 96.

76 R.A. Cadenhead, The Body and Desire. Gregory of Nyssa's Ascetical Theology, Oakland 2018, p. 57.

77 Cf. Tobon, Apatheia and Anthropology in Evagrius of Pontus (chapter 7, part 1).

78 Cf. Cadenhead, The Body and Desire, p. 163-164.

79 Gregorius Nyssenus, De virginitate 21, 2.6-14 (tr. M.T.).

80 Cf. Tobon, Apatheia and Anthropology in Evagrius of Pontus (chapter 1, part 5, chapter 8; part 10).

81 Cf. Tobon, Apatheia and Anthropology in Evagrius of Pontus (chapter 1, part 5). 
to sustain its life ${ }^{82}$. Its association with excess means that its presence in the soul reflects imbalance among its three constituent powers. Although neither of Nyssen's orations uses the term "pathos" in relation to the soul's disposition to sin, their insistence that virtue must be grounded in dietary abstinence, condemnation of excess, linking of these, and, as we shall now see, association of imbalance with bodily sickness and with vice, injustice, and alienation suggests essentially the same view.

\subsection{Correcting imbalance}

A key passage in De beneficentia likens social inequity to sickness on the grounds that both reflect imbalance. Following Nyssen's first reference to the plight of the poor he enjoins his congregants:

Let a fear of God level out the differences between you and [the naked and homeless]: through temperate self-control remedy two contrary pathe: your own satiety and the hunger of your brothers. This is how the physician works:

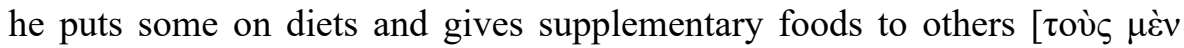
$\kappa \varepsilon v o \tilde{\sigma} \sigma$, $\tau$ ov̀ $\zeta \varepsilon \grave{\varepsilon} \pi \lambda \eta \rho \circ \tilde{\sigma l}$; literally, "he empties some and fills some"], so that by additions and subtractions health can be managed in each case. So follow this salutary advice ${ }^{83}$.

The word "pathe" here refers not to the ethical pathe but to the consequences of acting upon them; that is, to the state of affairs resulting from $\sin$. The idea of levelling out differences and use of the verb $\pi \lambda \eta \rho$ ó $\omega$ recall Isaiah 40:3-5, suggesting that here Gregory understands it in terms of reducing the soul's pathe and thus the societal injustice to which they dispose us. To do so is to restore the soul to balance and health, just as a physician seeks to restore the body to health by restoring the balance of its humours. The analogy of virtue to bodily health echoes both the Gorgias and the Republic ${ }^{84}$. In the former the physician is an exemplary practitioner of $\log \mathrm{s}^{85}$, and Nyssen explicitly links logos and the Logos to the healing of social inequity: "Let logos open the doors of the rich. [...] Let the eter-

82 Cf. Tobon, Apatheia and Anthropology in Evagrius of Pontus (chapter 7, part 1).

83 Gregorius Nyssenus, De beneficentia 97. Translations of De beneficentia and In illud: quatenus uni ex his fecistis mihi fecistis are by Holman with my own amendments.

${ }^{84}$ Cf. Plato, Gorgias 479ab; Plato, Respublica 444e; see above, 3.4.

85 Cf. Plato, Gorgias 456c, 464b-465d, 479ab. 
nal Logos of God give also a house and a light and table, by means of the household of the Logos" $"$. From the "naked and homeless who are everywhere visible" ${ }^{87}$ Nyssen proceeds to those who, being sick as well as poor, are doubly $\pi \tau \omega \chi$ ó $\varsigma$, and confined to their beds are unable to beg for alms but must await the visits of benefactors. To minister to them requires more effort, but since they bear the Saviour's countenance ( $\pi \rho$ ó $\sigma \omega \pi \circ \nu)$ no effort is too great ${ }^{88}$. The parable of the sheep and goats aims to teach the value of beneficence ${ }^{89}$, which like judgment and punishment redresses imbalance. Appealing to his congregants' possession of reason and intelligence, Nyssen enjoins them to cultivate temperance, moderate their needs, and share with the poor, instead of being deceived by ephemeral things into hording possessions for themselves while ignoring the needs of others ${ }^{90}$. He then paints a stark picture of inequity which introduces lepers as the most extreme embodiment of destitution. While hedonists devote themselves to pleasure,

a myriad of Lazaruses sit at the gate, some dragging themselves along painfully, some with their eyes gouged out, others with amputated feet, some quite literally creep, mutilated in all their members. They cry and are not heard over the flutes' whistling, loud songs, and the cackling of bawling laughter. If they beg more loudly at the door, the porter of a barbarous master bounds out like a brute and drives them away with strokes of a stick, setting the dogs on them and lashing their ulcers with whipcord ${ }^{91}$.

Houses such as this are shamed both by the excess of the revellers and

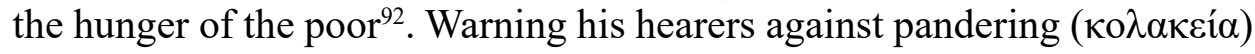
to the flesh Nyssen urges them to live in recollection of the fact that they will have to render account for how they have lived ${ }^{93}$. Insofar as they fail to observe measure in this life, payment will be demanded of them in the

86 Gregorius Nyssenus, De beneficentia 97. At In illud: quatenus uni ex his fecistis

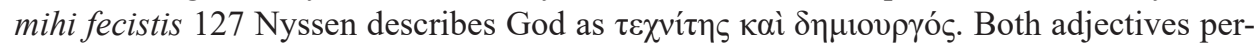

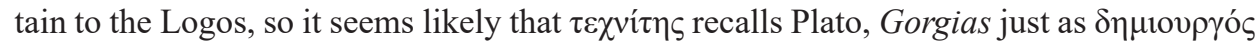
recalls Plato, Timaeus (e.g. 28a, 29a).

\footnotetext{
87 Gregorius Nyssenus, De beneficentia 97.

88 Cf. Gregorius Nyssenus, De beneficentia 97-98.

89 Cf. Gregorius Nyssenus, De beneficentia 100.

90 Cf. Gregorius Nyssenus, De beneficentia 103.

91 Gregorius Nyssenus, De beneficentia 105-106.

92 Gregorius Nyssenus, De beneficentia 105-106.

93 Cf. Gregorius Nyssenus, De beneficentia 107-108.
} 
next. He returns to the theme of judgment and condemnation at the start of Quatenus uni and speaks of his own fear of them ${ }^{94}$. He then embarks upon an extended description of the physical and emotional sufferings and social ostracisation of lepers. Alluding to the link between the pursuit of excess and alienation, he describes them as "born in the image of God, entrusted with the governance of the earth and the rule over all creatures", yet now "so alienated by sickness" as to be barely recognisable ${ }^{95}$ and urges his listeners not to "rend the unity ( $\delta i^{\alpha} \tau \alpha \xi 1 \varsigma$ ) of the Spirit" by "considering as strangers" those who "share the same nature as them" link between the pursuit of excess and lack of feeling, he asks why the sight of lepers does not move them to compassion ${ }^{97}$. Warning against judging by appearances alone, he tells them, "The hand is mutilated but it is not insensitive to assistance. The foot is gangrenous but always able to run to God; the eye is missing, but it discerns invisible goodness nonetheless, to the enlightenment of the soul ${ }^{98}$ ". Indeed, not only do the physical depredations of leprosy leave the soul unaffected, but according to ascetic theory they and the other sufferings of lepers should enhance its spiritual capacities. The Evagrian monk aims through asceticism to "strip off the weight of the flesh" 99 , both in its physical sense and in its psychological sense of worldly attachments, beginning with the monk's own worldly identity, so that both soul and body become more transparent to the presence of God. The physical symptoms and psychological and social consequences of leprosy as described by the Gregories mimic the effects of monastic asceticism, and in the next section we shall see that for Nyssen the bodies of lepers have a special ability to mediate grace to those who come into contact with them.

\subsection{Healing the soul by tending lepers' wounds}

The orations' ascent from the visible poor through the invisible poor to lepers aims not only to alleviate physical need but also to redress imbalance and alienation by overcoming social and psychological distance through personal contact. Having previously told his listeners that the

\footnotetext{
94 Cf. Gregorius Nyssenus, In illud: quatenus uni ex his fecistis mihi fecistis 112.

95 Gregorius Nyssenus, In illud: quatenus uni ex his fecistis mihi fecistis 116.

96 Gregorius Nyssenus, In illud: quatenus uni ex his fecistis mihi fecistis 114.

97 Cf. Gregorius Nyssenus, In illud: quatenus uni ex his fecistis mihi fecistis 115.

98 Cf. Gregorius Nyssenus, In illud: quatenus uni ex his fecistis mihi fecistis 122.

99 Evagrius, Eulogius prologue (tr. M.T).
} 
destitute "bear the countenance of our Saviour"100, he calls upon them to "embrace the wretched like gold", as they would their own health, family, and household ${ }^{101}$ and to imitate the Good Samaritan in neither recoiling from physical contact with them nor begrudging the means to meet their needs ${ }^{102}$. Recalling that God himself "put on this stinking and unclean flesh $[\ldots]$ in order to effect a total cure of [our] ills by his touch", he enjoins them to embrace the common bodily nature they share with the sick literally as well as metaphorically ${ }^{103}$. The ostracisation of lepers must be reversed, not merely alleviated:

Let no one say that some place far away from our life is perfectly sufficient and send them off to some frontier, supplying them with food. For a plan of this sort displays neither mercy nor sympathy but is designed, in the guise of goodwill, to banish these people utterly from our life ${ }^{104}$.

Described thus, such plans bear all the hallmarks of appetitive motivation since they do not aim at the true good either for lepers or for their benefactors (which by implication would be the same), but instead to give the latter the pleasure of feeling virtuous while sparing them the discomfort of seeing lepers. Viewed in this way, such plans are fundamentally dishonest, being exercises in self-deception rooted in the desire for appetitive gratification. The true good of both lepers and benefactors resides in overcoming the boundaries of prejudice and abuse that separate them and reflect both interior and societal imbalance. Nyssen's prescription for doing so culminates in his telling his congregants that in order to heal the wounds inflicted upon them by their sins - imagery that recalls the concluding myth of the Gorgias $^{105}$ - they should "heal today the ulcers that break down [lepers] flesh" ${ }^{106}$. As Holman notes, he is recommending a form of redemptive almsgiving that functions "by personal interaction with the sick body" 107 . This would have been asking a lot of his congregants. Engaged, compassionate touch is far more demanding than the material donations which, for those

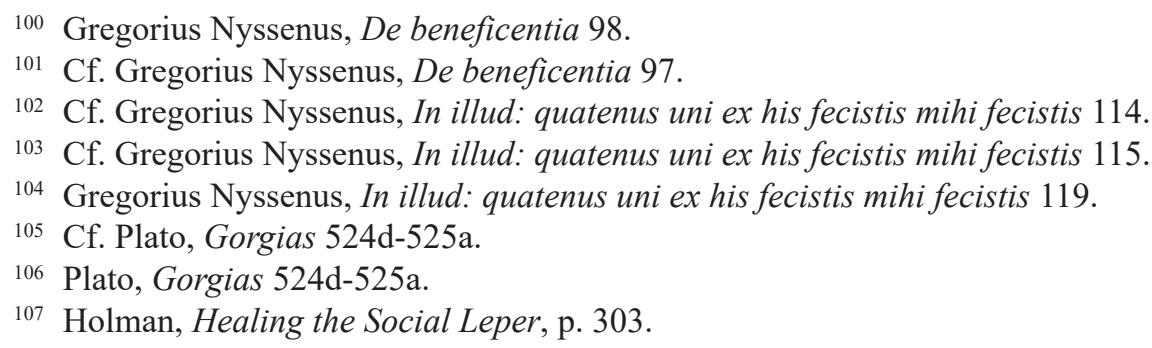


able to afford them, soothe consciences without requiring any real personal change. There is no escaping the raw physicality of bandaging wounds. In both its rigour and its emphasis on the body as a site of transformation the idea is of a piece with the ascetic tenor of these two orations, manifest already in their reference to corporeal and incorporeal abstinence ${ }^{108}$, custody of the tongue ${ }^{109}$, the philosophic life ${ }^{110}$, and interior watchfulness ${ }^{111}$; calls to compunction ${ }^{112}$; and now also in the language of Nyssen's pre-emptive response to his congregants' objections. Anticipating their complaint that it will be hard to overcome the loathing felt by the healthy in the presence of sickness ${ }^{113}$, he speaks of self-mastery, effort, sweat, toil, difficulty, value, hope, cure, perseverance, labour, the benefits of hard exercise, cites Matt. $7: 14$, and challenges them not to "beat a retreat in the face of the steep path of virtue" 114 . All of these belong to the lexicon of asceticism and by invoking them Nyssen is proclaiming the tending of lepers' wounds to be an ascetic goal for all Christians ${ }^{115}$. Although the orations do not use the technical vocabulary of pathos and apatheia, if we suppose the wounds inflicted upon the soul by sin to correspond to what the De virginitate and Evagrius call pathe, it would follow that tending lepers' physical wounds can lead

108 Cf. Gregorius Nyssenus, De beneficentia 94.

109 Gregorius Nyssenus, De beneficentia 94.

110 Cf. Gregorius Nyssenus, De beneficentia 95.

111 Gregorius Nyssenus, De beneficentia 95.

112 All three orations considered here are in their entirety calls to compunction.

113 Cf. Gregorius Nyssenus, In illud: quatenus uni ex his fecistis mihi fecistis 125.

114 Gregorius Nyssenus, In illud: quatenus uni ex his fecistis mihi fecistis 125.

115 The explicitly ascetic tenor of Nyssen's orations is consistent both their being delivered during Lent (see below, n.70) and with McGuckin's observation that Nazianzen "preferred the term $\sigma \omega \varphi \rho о \sigma u ́ v \eta$ to ö $\sigma \kappa \eta \sigma ı \varsigma$ the quest for wisdom and sobriety taking precedence over the disciplining of the body". However, the contrast should not be overstated. McGuckin also describes Nazianzen as a "self-professed ascetic" and speaks of the "rigorous nature of his asceticism", albeit within a context of material privilege. Petrakis describes how for Nazianzen philanthropy is "the fruit of the meeting between human volition in

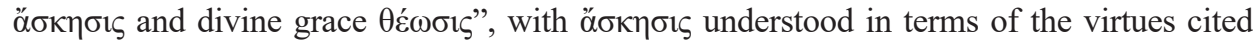
in the oration's initial paragraphs which together train the individual to "receive the experience of God". Cf. McGuckin, St. Gregory of Nazianzus on the Love of the Poor, p. 139141; V. Petrakis, Philanthropia as a Social Reality of Askesis and Theosis in Gregory the Theologian's Oration On the Love for the Poor, in: Philanthropy and Social Compassion in the Eastern Orthodox Tradition, ed. M.J. Pereira, New York 2010, p. 91, 97. For both Gregories' association of asceticism and the imago Dei with social justice, cf. I.L.E. Ramelli, Social Justice and the Legitimacy of Slavery: The Role of Philosophical Asceticism from Ancient Judaism to Late Antiquity, Oxford 2016, p. 172-231 (chapters 5-7). 
to what Evagrius calls apatheia by facilitating in the agent's soul a transformation equivalent to that wrought by monastic asceticism ${ }^{116}$. I take this to correspond to the "reverse contagion" described by Holman whereby lepers function as "channels of divine sanctity", direct contact with whose bodies can heal spiritual wounds ${ }^{117}$.

\subsection{Conclusion}

Nyssen's orations trace an ascetic ascent from a fleshly way of life characterised by appetitive excess to a spiritual way of life characterised by measure. The ascent begins with physical abstinence in the form of fasting and proceeds through abstinence from dishonesty and injustice to the practice of ever increasing levels of charity, beginning with material support for the poor, proceeding through support for those who are both poor and sick, then extending also to lepers, and culminating in personally tending their wounds. Since both social inequity and personal vice involve imbalance, both are analogous to bodily sickness and like it have their remedy in recourse to logos.

\section{Going forth to the peripheries}

In his Apostolic Exhortation Evangelii Gaudium Pope Francis speaks of how God challenges Christians to "go forth from our own comfort zone in order to reach all the «peripheries» in need of the light of the Gospel"118. This is precisely what these orations ask of us. In situating lepers as the epitome of destitution the Gregories call Christians to take "the light of the Gospel" to the peripheries of their social world in the form of practical charity, and in doing so to venture beyond a comfortable practice of virtue by overcoming their prejudice towards lepers. The peripheries to which they call us are thus both exterior and interior, social and psychological. Calleja takes up this point in his approach to the three orations as "a blue-

116 The recognition of care-giving as spiritually equivalent to monastic asceticism is attested by Palladius, Historia Lausiaca 21, 3-14; cf. M. Tobon, Disability in the Early Church, in: The T\&T Clark Handbook of the Early Church, ed. P. Ashwin-Siejkowski I.L.E. Ramelli - J.A. McGuckin, London 2021 (forthcoming).

117 Cf. Holman, Healing the Social Leper, p. 303.

118 Franciscus, Evangelii Gaudium 1, 20. 
print for exhorting solidarity with the socially alienated today" 119 and raises the question of who the figure of the leper symbolises in today's world. Noting that for Wessel the leper in Oration 14 is "a kind of synedoche [i.e. a part representing the whole] for all human suffering", and that Holman "focuses on their social dimension [...] as figures of social exile", he proposes as a third candidate "that person who is suffering and exiled from $m y$ landscape because in $m y$ eyes that person's «skin» is flawed" [italics Calleja's] ${ }^{120}$. He explains that what we perceive to be blemishes on a person's skin, whether wrinkles, birth marks, tattooes, piercings, scars, or stretch marks can, through their "exposure of vulnerability", "elicit subtle responses of exclusion within us""121.

While endorsing all of these suggestions and acknowledging the especial "fit" of Calleja's to leprosy in its appeal to perceived disruptions to the skin, I would like to add two more. The first is that the mutilated, scarred, and abused leper symbolises the earth, mutilated, scarred, and abused by our failure to observe measure and described by Pope Francis in his Encyclical Letter Laudato Si' as "among the most abandoned and maltreated of the poor" 122 . The pursuit of excess, lack of feeling for others, and defiance of logos and the Logos to which the Gregories attribute the plight of lepers find their most far-reaching expression of all in our destruction of the earth whose cry, as Francis and Boff point out, is also "the cry of the poor" 123 . In that destruction we now see as a matter of unprecedented scope and urgency the need to learn temperance, moderate our needs, and embrace the most vulnerable: not only (but most emphatically) our disadvantaged human siblings but also our "common home" 124 and life support system, and the other creatures with whom we share it, each of whom has their "own value and significance [within God's loving plan]"125, but many of whom are now threatened in their very existence by our irresponsible activity. Relatedly, the Covid-19 pandemic which at the time of writing continues to devastate

119 C. Calleja, The Orations of the Cappadocian Fathers on Lepers: A Blueprint for Exhorting Solidarity with the Socially Alienated Today, "Lumen et Vita" 9/2 (2019) p. 1-20.

120 Calleja, The Orations of the Cappadocian Fathers on Leper, p. 3-4, citing S. Wessel, The Suffering of Christ, Humanity and the Lepers in Gregory Nazianzen, "Scottish Journal of Theology" 68/4 (2015) p. 397.

121 Calleja, The Orations of the Cappadocian Fathers on Leper, p. 4.

122 Franciscus, Laudato Si' 2.

123 Franciscus, Laudato Si' 49; L. Boff, Cry of the Earth, Cry of the Poor, Maryknoll 1997.

124 Franciscus, Laudato $\mathrm{Si}$ ' 1.

125 Franciscus, Laudato Si' 276. 
human life and livelihood in many parts of the world is presumed (although not confirmed) to have originated in a wet food market where wild creatures of different species were kept in conditions of great cruelty in which the proximity of different species and of the living to the dead would have facilitated the zoonotic transmission of viruses ${ }^{126}$. De beneficentia speaks eloquently to such scenarios in its description of gourmands who "[make themselves destroyers] of absolutely all living things" 127 .

My second suggestion for the symbolic value of the leper takes up the dual nature of the peripheries as being psychological as well as social and is one that I take to be implicit in both Oration 14 and Quatenus uni, given their highlighting of the bodily nature that we share with lepers. It is that the leper represents the bodily weakness which, because we are unwilling to face it in ourselves, we banish to the peripheries of our self-awareness and reject when we see it in others, leading us to reject those others themselves. As the most destitute of all, lepers include all of its possible expressions. We attempt to mask our vulnerability and mortality with sensual pleasure and material security, failing to realise that in doing so we bind ourselves to them by choosing the body as our $\mu$ oi $\rho \alpha$ so that it becomes for us "the body of this death" ${ }^{128}$. In describing his own experience of the body's troublesome nature Nazianzen shows his listeners how to acknowledge and embrace "the weakness to which we are harnessed" 129 and invites them to do the same. Only then does he attempt to awaken them to compassion for lepers. Only when we have acknowledged and accepted our vulnerability can we embrace it as a teacher of piety and kindness ${ }^{130}$ and reminder of our dependence on God. To do so is to realise our full humanity as a mixed nature $(\kappa \rho \tilde{\alpha} \mu \alpha)^{131}$, meaning that to realise our full humanity we must go forth to the peripheries interiorly as well as exteriorly. This in turn is to foster balance in ourselves by assigning due measure to both our bodily nature and our status as icons of God, meaning that in the soul as in society

126 Cf., e.g., R. Tiwari - K. Dhama - K. Sharun - M. Iqbal Yatoo - Y.S. Malik - R. Singh - I. Michalak - R. Sah - D.K. Bonilla-Aldana - A.J. Rodriguez-Morales, COVID-19: animals, veterinary and zoonotic links, "Vet Q" 40/1 (2020) p. 169-182. My intention is not to single out a particular culture but rather a type of practice. Western-style methods of meat and dairy production also involve great cruelty; cf., e.g., Compassion in World Farming, in: https://www.ciwf.org.uk (access: 20.01.2021).

127 Gregorius Nyssenus, De beneficentia 104.

128 Cf. Rom. 7:24-25; see above, 3.2.

129 Gregorius Nazianzenus, Oratio 14, 7.

130 Cf. Gregorius Nazianzenus, Oratio 14, 15.

131 Gregorius Nazianzenus, Oratio 14, 15. 
imbalance is most fully redressed at the peripheries. And since measure and balance are characteristics of the Logos, to realise them in ourselves is to be conformed to Christ and gathered into God.

While Nazianzen gives greater attention to accepting our own bodily weakness through introspection, Nyssen gives greater attention to personal contact with the bodies of lepers. Both approaches involve going forth to the peripheries of our psychological comfort zone, Nazianzen's in relation to confronting our own bodily vulnerability (which we saw to be both physical and moral) ${ }^{132}$ and Nyssen's in relation to overcoming our loathing for lepers' bodies. Each contains the other in the sense that accepting our own vulnerability awakens our compassion and solidarity for lepers, and accepting lepers' bodies should enable us to accept our own vulnerability. They are therefore complementary routes to awakening to our own true humanity, recognising that of lepers, and making good the imbalance reflected in our denial of our vulnerability and our neglect of lepers. Recognising them as different routes to the same destination can perhaps illuminate the contrasting attitudes to the Basileias evident in Nazianzen's Oration 43 and Quatenus uni. We have seen that Oration 14 recommends, in addition to material provision for lepers, keeping them company, showing them compassion and sympathy, and bandaging their wounds, and emphasises that to do so is to do these things to Christ ${ }^{133}$. Oration 43 makes it clear that they can be done in an institutional setting, Nazianzen praising Basil for taking the lead in attending to lepers and greeting them as his brethren, and for the fact that, in virtue of the construction of the Basileias, lepers are no longer to be seen in public places ${ }^{134}$. By contrast Nyssen, as we have seen, explicitly condemns such schemes as dishonest and devoid of compassion; as Holman notes, "that which Gregory of Nazianzus praises in Oration 43 - that because of Basil's institution the destitute are now out of sight - is precisely what Gregory of Nyssa condemns"135. Yet it is clear from Nazianzen's anthropology that he no less than Nyssen would have considered the overcoming of social and psychological barriers separating lepers from the rest of society the ideal, an inference supported by his references to being guided by "our original egalitarian status" 136 and imitating

132 See above, 3.2 .

133 Gregorius Nazianzenus, Oratio 14, 27-28, 40; see above, 3.5.

134 Cf. Gregorius Nazianzenus, Oratio 43, 63.

135 Holman, The Hungry are Dying, p. 147.

136 Gregorius Nazianzenus, Oratio 14, 26. 


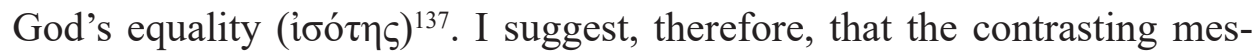
sages of Oration 43 and Quatenus uni can be explained at least in part by the different contexts for which they were composed, the former a funeral oration celebrating Basil's achievements, the latter a Lenten oration exhorting an ascetic ideal. Also germane, however, is Meredith's observation that "Gregory of Nazianzus' attitude to the spiritual life, is at any rate verbally [italics mine], far more traditional than that of Gregory of Nyssa" 138 . Nazianzen's views as to the ideal are perhaps closer to Nyssen's than his words suggest, while in turn it is hard to believe that Nyssen would have denied the benefits to lepers of institutional care even if the concept of such care is less than ideal.

\section{Conclusion}

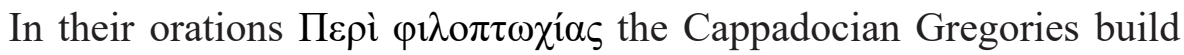
upon Plato's association of measure with logos and excess with appetite, articulated in the Gorgias and reflected, via the Stoics, in Evagrius. They associate appetite, and so the pursuit of excess, with the body, and appropriate measure and balance to the Christian Logos. Both suppose that a society's inequity reflects the soul sickness of its members, a sickness rooted in a failure to distinguish between merely apparent goods and the true good. Deceived by ephemera, we have lost sight of our true nature and dignity, our essential kinship with other human beings, God's providential care for us, and our vocation to imitate that care by observing the priority of practical love. Consequently we have lost sight of our own true humanity. The remedy is to restore balance to our souls and to society by practising mercy and compassion, especially to the most destitute, in serving whom we serve Christ himself. This means going forth to the peripheries of our social world and psychological comfort zone, bearing the light of the gospel to each in the form appropriate to it. It is at the peripheries, both exterior and interior, that our excessive attachment to the flesh and deficient love for God and neighbour are most effectively addressed and due measure restored, and thus our true humanity most fully realised. These orations invite empathy for all victims of disease, destitution, and rejection, and confront our tendency to turn away from suffering by challenging our prejudices and

137 Gregorius Nazianzenus, Oratio 14, 24, 26; see above, 3.5.

138 A. Meredith, Gregory of Nazianzus and Gregory of Nyssa on Basil, "Studia Patristica" 32 (1997) p. 167. 
recalling us to humankind's essential goodness and capacity for love and the possibility of personal and social transformation through following the Logos.

\section{The Normativity of Measure in Gregory Nazianzus' and Gregory of Nyssa's Orations on Love for the Destitute Poor}

(summary)

Gregory Nazianzus and Gregory of Nyssa between them composed three orations On love for the destitute poor which highlight the pre-eminence for Christians of practical charity, situate lepers as its most deserving recipients, and argue that to minister to the poor is to minster to Christ himself. This paper focuses on their use of categories from Plato's Gorgias to analyse social inequity in terms of the pursuit of excess associated with the appetites and its remedy in restoring measure and balance associated with logos, appropriated by the Gregories to the Christian Logos such that the pursuit or tolerance of excess, or of its concomitants deficiency and imbalance, is shown to be incompatible with Christian faith. While the Gregories' core argument is the same, their approaches differ, Gregory of Nyssa's being more explicitly ascetic. After outlining the late antique notion of the $\pi \tau \omega \chi 0$ í and the salient aspects of Plato's Gorgias, I turn to the three orations, focusing on how they appeal to excess, measure, and balance in diagnosing soul sickness and prescribing its remedy. I conclude by discussing their anticipation of Pope Francis' call to "go forth to the peripheries", considering who the figure of the leper symbolises for us today and, implicitly, for the Gregories, and how this discussion can illuminate the apparent contrast between Nazianzen's and Nyssen's views of institutional care for lepers.

Keywords: Gregory of Nazianzus; Gregory of Nyssa; leper; poor; excess; appetite; pathos; temperance; body; ascetic; mercy; Covid-19; Basileias; Gorgias; Evangelii Gaudium; Laudato $\mathrm{Si}^{\prime}$

\section{Bibliography}

\section{Sources}

Basilius Caesariensis, Regulae brevius tractatae 262, PG 31, 1052-1305.

Dionysius Areopagita, De caelesti hierarchia, ed. G. Heil - A.M. Ritter, Corpus Dionysiacum ii: Pseudo-Dionysius Areopagita. De coelesti hierarchia, de ecclesiastica hierarchia, de mystica theologia, epistulae, Patristische Texte und Studien 36, Berlin 1991, p. 7-59.

Euripides, Phoenissae, in: Euripidis fabulae, v. 3, ed. J. Diggle, Oxford 1994, p. 83-179. Euripides, Phoenician Women, in: Euripides: Helen, Phoenician Women, Orestes, ed. and tr. D. Kovacs, Cambridge 2014. 
Evagrius Ponticus, De malignis cogitationibus, in: Évagre le Pontique: Sur les pensées, ed. A. Guillaumont - C. Guillaumont - P. Géhin, SCh 438, Paris 1998.

Evagrius Ponticus, Tractatus ad Eulogium (sub nomine Nili Ancyrani), PG 79, 1093-1140. Franciscus, Apostolic Exhortation on the Joy of the Gospel Evangelii Gaudium (24 November 2013), in: http:/www.vatican.va/content/francesco/en/apost_exhortations/ documents/ papa-francesco_esortazione-ap_20131124_evangelii-gaudium.html (access: 20.01.2021).

Franciscus, Francisci Summi Pontificis Litterae Encyclicae Laudato Si’ De Communi Domo Colenda (24.05.2015), in: http://www.vatican.va/content/francesco/la/encyclicals/ documents/papa-francesco_20150524_enciclica-laudato-si.html (access: 20.01.2021).

Gregorius Nazianzenus, De pauperem amore (orat. 14), PG 35, 857-909, tr. M. Vinson, St. Gregory of Nazianzus. Select Orations, The Fathers of the Church, Washington 2003, p. 39-71.

Gregorius Nazianzenus, Funebris oratio in laudem Basilii Magni Caesareae in Cappadocia episcopi (orat. 43), in: Grégoire de Nazianze. Discours funèbres en l'honneur de son frère Césaire et de Basile de Césarée, ed. F. Boulenger, Paris 1908, p. 58-230.

Gregorius Nyssenus, De beneficentia (vulgo De pauperibus amandis i), in: Gregorii Nysseni opera, v. 9/1, ed. A. van Heck, Leiden 1967, p. 93-108, tr. S.R. Holman, The Hungry are Dying: Beggars and Bishops in Roman Cappadocia, Oxford 2001, p. 193-199.

Gregorius Nyssenus, De virginitate, ed. M. Aubineau, SCh 119, Paris 1966.

Gregorius Nyssenus, In illud: Quatenus uni ex his fecistis mihi fecistis (vulgo De pauperibus amandis ii), in: Gregorii Nysseni opera, v. 9/1, ed. A. van Heck, Leiden 1967, p. 111-127, tr. S.R. Holman, The Hungry are Dying: Beggars and Bishops in Roman Cappadocia, Oxford 2001, p. 199-206.

Origenes, Fragmenta in Psalmos, PG 12, 1201B, tr. G. Hamel, Poverty and Charity in Roman Palestine, First Three Centuries C.E., Near Eastern Studies 23, Berkeley 1990.

Palladius, Historia Lausiaca (recensio G), in: Palladio. La storia Lausiaca, ed. G.J.M. Bartelink, Verona 1974.

Plato, Gorgias, in: Plato: Gorgias, ed. E.R. Dodds, Oxford 1959.

Plato, Gorgias, tr. T. Irwin, Plato: Gorgias, Oxford 1979.

Plato, Leges, in: Platonis opera, v. 5, ed. J. Burnet, Oxford 1907.

Plato, Respublica, in: Platonis Rempublicam, ed. S.R. Slings, Oxford 2003.

Plato, Timaeus, in: Platonis opera, v. 4, ed. J. Burnet, Oxford 1902.

\section{Studies}

Boff L., Cry of the Earth, Cry of the Poor, Maryknoll 1997.

Cadenhead R.A., The Body and Desire. Gregory of Nyssa's Ascetical Theology, Oakland 2018. 
Calleja C., The Orations of the Cappadocian Fathers on Lepers: A Blueprint for Exhorting Solidarity with the Socially Alienated Today, "Lumen et Vita" 9/2 (2019) p. 1-20.

Holman S.R., Healing the Social Leper in Gregory of Nyssa's and Gregory of Nazianzus's

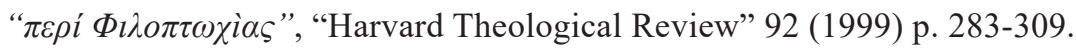

Holman S.R., The Hungry are Dying. Beggars and Bishops in Roman Cappadocia, Oxford 2001.

Holmes B., The Symptom and the Subject. The Emergence of the Physical Body in Ancient Greece, Princeton 2010.

Kahn C.H., Plato and the Post-Socratic Dialogue. The Return to the Philosophy of Nature, Cambridge 2013.

Long A.A., Heraclitus on measure and the explicit emergence of rationality, in: Body and Soul in Ancient Philosophy, ed. D. Frede - B. Reis, Berlin 2009, p. 87-110.

McGuckin J.A., Saint Gregory of Nazianzus. An Intellectual Biography, Crestwood 2001.

McGuckin J.A., St. Gregory of Nazianzus on the Love of the Poor (Oration 14), in: The Ecumenical Legacy of the Cappadocians, ed. N. Dumitrascu, Basingstoke 2016, p. 139-157.

Meredith A., Gregory of Nazianzus and Gregory of Nyssa on Basil, "Studia Patristica" 32 (1997) p. 163-169.

Milovanović Č., "Here I am a Breathing Corpse”: did Gregory of Nazianzus Suffer from Leprosy?, “Analecta Bollandiana” 127 (2009) p. 273-297.

Petrakis V., Philanthropia as a Social Reality of Askesis and Theosis in Gregory the Theologian's Oration On the Love for the Poor, in: Philanthropy and Social Compassion in the Eastern Orthodox Tradition, ed. M.J. Pereira, New York 2010, p. 90-105.

Ramelli I.L.E., Evagrius and Gregory: Nazianzen or Nyssen? Cappadocian (and Origenian) Influence on Evagrius, "Greek, Roman, and Byzantine Studies" 53 (2013) p. 117-137.

Ramelli I.L.E., Social Justice and the Legitimacy of Slavery: The Role of Philosophical Asceticism from Ancient Judaism to Late Antiquity, Oxford 2016.

Religion and the Body, ed. S. Coakley, Cambridge 1997.

Rousseau P., Basil of Caesarea, Berkeley 1994.

Shields C., Simple Souls, in: Essays on Plato's Psychology, ed. E. Wagner, Lanham 2001, p. 137-156.

Tiwari R. - Dhama K. - Sharun K. - Iqbal Yatoo M. - Malik Y.S. - Singh R. - Michalak I. - Sah R. - Bonilla-Aldana D.K. - Rodriguez-Morales A.J., COVID-19: animals, veterinary and zoonotic links, "Vet Q" 40/1 (2020) p. 169-182.

Tobon M., Apatheia and Anthropology in Evagrius of Pontus, London 2021.

Tobon M., Disability in the Early Church, in: The T\&T Clark Handbook of the Early Church, ed. P. Ashwin-Siejkowski - I.L.E. Ramelli - J.A. McGuckin, London 2021.

Wessel S., The Suffering of Christ, Humanity and the Lepers in Gregory Nazianzen, "Scottish Journal of Theology" 68/4 (2015) p. 381-397. 